$\overline{\text { 原 著 }}$

\title{
破裂脳動脈瘤軽症例における術後悪化例の検討
}

\author{
佐藤 崇, 貫井 英明, 三塚 繁, 保坂 力 ${ }^{1}$ \\ 柿沢 敏之, 西ヶ谷和之, 八木下 勉, 橋爪 和弘 ${ }^{1}$ \\ 佐々木秀夫, 長屋 孝雄 $^{3}$
}

\section{Analysis of Causes of Deterioration in Cases with Ruptured Aneurysms Classified into Grade I or II by Hunt and Kosnik's Classification}

Takashi Sato, M.D., ${ }^{1}$ Hideaki Nukui, M.D., ${ }^{1}$ Shigeru Mitsuka, M.D., ${ }^{1}$

Tsutomu Hosaka, M.D., ${ }^{1}$ Toshiyuki Kakizawa, M.D., ${ }^{1}$

Kazuyuki Nishigaya, M.D., ${ }^{1}$ Tsutomu Yagishita, M.D., ${ }^{1}$

Kazuhiro Hashizume, M.D., ${ }^{1}$ Hideo Sasaki, M.D., ${ }^{2}$

and Takao NAGAYA, M.D. ${ }^{3}$

${ }^{1}$ Department of Neurosurgery, Yamanashi Medical University, Yamanashi,

${ }^{2}$ Department of Neurosurgery, Kofu-jonan Hospital, Kofu, and

${ }^{3}$ Maebashi Neurosurgical Hospital, Maebashi, Japan

Summary : We evaluate the causative factors of deterioration after surgery for ruptured aneurysm in the cases of Grade I or II, where good outcomes are generally anticipated.

In cases operated on within 3 days after SAH, poor outcome was found in 8 cases (13\%) out of 56 cases in Grade I. Poor outcome was also found in 12 cases (11\%) out of 110 cases in Grade II. Causes of deterioration in Grade I were vasospasm (VS) in 4, common carotid artery occlusion with unknown causes in 1 and other complications in 3. In Grade II causes, patients deteriorated because of VS in 6, surgical procedures for high-positioned BA aneurysm, VA dissecting aneurysm and IC aneurysm.

In cases operated on between 4 and 14 days after $\mathrm{SAH}$, outcome was poor in $4(6 \%)$ out of 74 Grade I cases. Outcome was also poor in $2(9 \%)$ out of 23 Grade II cases. Causes of deterioration in Grade I were surgical procedures for ICA-AN and VBA-AN, VS in 1, complication in 1. In Grade II causes were surgical procedure for dorsal ICA-AN and, VS in 1.

In cases operated on the day 15 or later after SAH, outcome was poor in 8 (4\%) out of 222 Grade I cases. Cause of deterioration in this group were surgical procedures for VBA-AN in 3, ICA-AN and MCA-AN in 1, VS in 1 and other complications in 2.

In summary, VS was the cause of deterioration in many cases of the early operation group, especially in patients over 65 years old.

In the late operation group, surgical procedures were the most common cause of deterioration, especially in patients over 65 years old and in cases with VB aneurysm.
Key words :

- ruptured cerebral aneurysm

- Grade I and II

- operative results

- causes of deterioration

${ }^{1}$ 山梨医科大学 脳神経外科, ${ }^{2}$ 甲府城南病院 脳神経外科, ${ }^{3}$ 前橋脳神経外科病院(受稿日 1995.12.11)〔連絡先： $\overline{7} 409-38$ 山梨県中巨 摩郡玉穂町下河東 1110 山梨医科大学 脳神経外科 佐藤 崇] [Mailing address: Takashi SATO, M.D., Department of Neurosurgery, Yamanashi Medicine, College, 1110 Shimokato, Tamaho-machi, Nakakoma-gun, Yamanashi 409-38, Japan] 


\section{はじめに}

破裂脳動脈瘤の治療成績について多くの報告が散見され る12)5（8) 9) 11) 12) 13) 15) 18) 22) 23) 。その中で破裂脳動脈瘤重症 例における転帰不良の原因は出血による primary brain damageとvasospasm(VS)であると報告されている.

一方, Grade I およびII の破裂脳動脈瘤症例の手術成 績については，転帰良好例が $80 \%$ 以上であり一般に良好 とされる (8)9) 19) 23) が，少数例にせよ不良な転帰をとる症 例もある. このような転帰不良例の原因を追求し, 手術成 績をさらに向上させることは重要なことと考えられる．し かし，過去においてこのような検討を行った報告は我々が 涉猟し得た限り見あたらない.

そこで，軽症破裂脳動脈瘤の転帰不良例の原因を著者ら のシリーズより retrospectiveに検討した。

\section{対象および方法}

検討の対象とした症例は, 山梨医科大学附属病院および その関連施設に扔いて 1994年 8 月までに手術を行った破 裂脳動脈瘤軽症例で, 術前の付帯事項を付けないHunt \& Kosnik 分類 ${ }^{4)}$ の Grade I : 352 例, Grade II : 133 例の計 485 例である。なお, Grade Iaの症例は除外した。

最終クモ膜下出血後 3 日以内に手術を施行された 166 例 (3 日以内手術群) では, Grade I が56 例, Grade II が 110 例であった。年齢は，65 歳未満が 124 例， 65 歳以上 が 42 例で, それらの動脈瘤存在部位は内頸動脈 (ICAAN) 52 例, 中大脳動脈 (MCA-AN) 30 例, 前交通動脈 (AComA-AN) 48 例, 前大脳動脈近位部動脈 $\left(\mathrm{A}_{1}-\mathrm{AN}\right) 3$ 例, 前大脳動脈遠位部動脈 (DACA-AN) 10 例, 椎骨脳底 動脈 (VBA-AN) 23 例であった.

4 日から 14 日に手術を施行された 97 例 (4-14日手術群) では，Grade I ，IIがそれぞれ 74 例，23 例であり，65歳 未満 77 例， 65 歳以上 20 例であった。動脈瘤存在部位は ICA-AN 32 例, MCA-AN 12 例, AComA-AN 29 例, $\mathrm{A}_{1}$-AN 1 例，DACA-AN 7 例，VBA-AN 16 例であった。 15 日以降に手術を施行された 222 例 (15 日以降手術群) では，全例 Grade I であり，65 歳未満 184 例，65 歳以上 38 例であった。動脈瘤存在部位は ICA-AN 56 例，MCAAN 39 例, AComA-AN 74 例, $\mathrm{A}_{1}$-AN 3 例, DACA-AN 4 例, VBA-AN 46 例であった.

多発脳動脈瘤症例については破裂した部位を記載した。

手術はDACA-AN，椎骨動脈瘤を除き一側 pterional approachにて施行し, 必要に応じて脳槽ドレナージを行 った，脳血管攣縮の治療としては，20\% mannitol および steroid の投与を行い，必要に応じて昇圧療法，抗血小板 剂も追加した。
転帰は術後 3 カ月以上の時点で以下の 5 段階に判定した。 excellent：神経脱落症状なし

good：軽度の神経脱落症状はあるが, 社会生活可能 fair：社会生活は不可能だが，独力あるいは一部介助に て家庭生活可能

poor：家庭生活に全介助を要す

dead : 死亡

また，この中で fair 以下の例を転帰不良とし，その原 因を, 脳血管攣縮 (vasospasm, VS), 手術操作 (surgical procedure, SP), 術後合併症 (complication, Comp.) に分類 し検討した。なお，術直後より新たな神経脱落症状を生じ, その後の経過観察中に全身状態の悪化により転帰不良とな った例は SP 群に分類した。

統計学的処理は $\chi^{2}$ 検定を用いた.

\section{結果}

\section{[3 日以内手術群]}

転帰不良は Grade I では 8 例 (13\%), Grade IIでは 12 例 (11\%)であった (Table 1,2)。転龠不良の原因は，VS が最も多く 10 例 (6\%)で，次いで Comp. 7 例 ( $4 \%$ ), $\mathrm{SP} 3$ 例 (2\%)であり, VS の 10 例は Grade I 4 例 ( $6 \%$ ), Grade II 6 例 ( $5 \%$ )であった (Table 3). Grade I, II を 合わせて VSによる転帰不良を年齢別に検討すると， 65 歳未満が 124 例中 4 例 ( $3 \%$ )に比し, 65 歳以上は 42 例中 6 例 $(14 \%)$ と VSによる転帰不良例が有意に高率に認めら れた $(p<0.02)$. SPによる転帰不良のうち， 1 例は 72 歳の Grade II の例で, 高位に存在した脳底動脈先端部動 脈瘤の clipping の際，穿通枝の閉塞をきたした例であっ た. 他の 1 例は 72 歳の ICA-AN で未破裂の MCA-AN お よびBA-SCA junction-AN を合併した例であり，3 個の AN に対し clipping を施行したが，術中所見では周囲血管 閉塞や血管損傷は認められなかった。しかし，術後に片麻 痺を生じ，CT上，基底核部に低吸収域がみられた。意識 は清明にて経過したが，片麻痺のため床上安静の期間が長 期に及び，肺炎，DICを併発し死亡した例である。残り の 1 例は解離性椎骨動脈瘤で，当初 clipping を試みた例 であり，この操作により動脈瘤壁からの血栓が脳幹への穿 通枝を閉塞したものであった。Comp. が認められた 7 例 中, Grade Iの 1 例は術後原因不明の内頸動脈閉塞, 1 例が Grade II で手術した ICA-AN で，術直後曈孔散大を きたし，死亡した例である。その CT 所見から，術前脳血 管撮影が行われなかったVBA-AN が破裂したものと判断 された. 1 例は 70 歳の MCA-AN であり, 術後の経過は 良好であったものの，術後 1 力月で基底核部に脳内出血を 生じたため, Comp. 群とした例である. 他の 1 例が 72 歳 で術後に肺炎と DIC を併発し死亡した例であり，残りの 
Table 1 Surgical outcome in Grade I cases with ruptured cerebral aneurysms operated on within 3 days after SAH

\begin{tabular}{lrrrrrrr}
\hline \multirow{2}{*}{$\begin{array}{c}\text { Site of ruptured } \\
\text { aneurysm }\end{array}$} & \multicolumn{5}{c}{ Surgical outcome } & Total \\
\cline { 2 - 6 } & Excellent & Good & Fair & Poor & Dead & \\
\hline ICA & 9 & 2 & 1 & 0 & 0 & 12 \\
MCA & 10 & 0 & 1 & 0 & 1 & 12 \\
AComA & 17 & 1 & 2 & 1 & 1 & 22 \\
A $_{1}$ & 2 & 0 & 0 & 0 & 0 & 2 \\
DACA & 2 & 0 & 0 & 0 & 0 & 2 \\
VB & 4 & 1 & 0 & 1 & 0 & 6 \\
\hline Total & 44 & 4 & 4 & 2 & 2 & 56 \\
\hline
\end{tabular}

ICA: internal carotid artery, MCA: middle cerebral artery, AComA: anterior communicating artery, $\mathrm{A}_{1}$ : $\mathrm{A}_{1}$ portion of anterior cerebral artery, DACA: distal portion of anterior cerebral artery, VB: vertebrobasilar artery

Table 2 Surgical outcome in Grade II cases with ruptured cerebral aneurysms operated on within 3 days after SAH

\begin{tabular}{lcccccc}
\hline \multirow{2}{*}{$\begin{array}{c}\text { Site of ruptured } \\
\text { aneurysm }\end{array}$} & \multicolumn{5}{c}{ Surgical outcome } & \\
\cline { 2 - 6 } & Excellent & Good & Fair & Poor & Dead & \\
\hline ICA & 33 & 1 & 2 & 1 & 3 & 40 \\
MCA & 17 & 1 & 0 & 0 & 0 & 18 \\
AComA & 22 & 2 & 1 & 0 & 1 & 26 \\
$\mathrm{~A}_{1}$ & 1 & 0 & 0 & 0 & 0 & 1 \\
DACA & 8 & 0 & 0 & 0 & 0 & 8 \\
VB & 9 & 4 & 2 & 1 & 1 & 17 \\
\hline Total & 90 & 8 & 5 & 2 & 5 & 110 \\
\hline
\end{tabular}

ICA: internal carotid artery, MCA: middle cerebral artery, AComA: anterior communicating artery, $\mathrm{A}_{1}: \mathrm{A}_{1}$ portion of anterior cerebral artery, DACA: distal portion of anterior cerebral artery, VB: vertebrobasilar artery

2 例が 76 歳と 81 歳の例で，長期臥床による廃用性の筋力 低下をきたした例であった。

\section{[4-14 日手術群]}

転帰不良は Grade Iでは 4 例 (6\%)，Grade II では 2 例 ( $9 \%$ )であった (Table 4,5).

転㷌不良の原因は, VS 2 例 ( $2 \%), \operatorname{SP} 3$ 例 ( $3 \%)$, Comp. 1 例 ( $1 \%)$ であった (Table 6). VSの 2 例は 58 歳の Grade I の AComA-AN, 64 歳の Grade II の MCAAN の症例である. SP による転帰不良の内訳は， 1 例が VBA-ANであり，他の 2 例が ICA-AN であった. VBA. ANの 1 例は 77 歳の Grade I の例で, 高位の脳底動脈先 端部動脈瘤であり, clipping により後大脳動脈㧍よびその 穿通枝の閉塞を生じたものであったＩCA-ANの 1 例は,
Table 3 Causes of deterioration in Grade I and II cases with ruptured aneurysms (Cases operated within 3 days)

\begin{tabular}{cccccc}
\hline Age & (Total cases) & VS & SP & Comp. & Total \\
\hline$<65$ & $(124)$ & 4 & 1 & 2 & 7 \\
$65 \leqq$ & $(42)$ & 6 & 2 & 5 & 13 \\
\hline & $(166)$ & $10(6 \%)$ & $3(2 \%)$ & $7(4 \%)$ & $20(12 \%)$
\end{tabular}

VS: vasospasm, SP: surgical procedure, Comp.: complication

fetal type の後交通動脈分岐部に動脈瘤を生じた 84 歳の症 例で，術中所見では後交通動脈が温存されたことを確認し たが, 術後に後大脳動脈領域全域と基底核部に梗塞が生じ 片麻痺をきたし，結果的に寝たきり状態となった例である. 他の 1 例はいわゆるチマメ状動脈瘤 ${ }^{21)}$ であり, 当初 clip- 
Table 4 Surgical outcome in Grade I case with ruptured cerebral aneurysms operated between 4 and 14 days after SAH

\begin{tabular}{lrrrrrr}
\hline \multirow{2}{*}{$\begin{array}{c}\text { Site of ruptured } \\
\text { aneurysm }\end{array}$} & \multicolumn{5}{c}{ Surgical outcome } & Total \\
\cline { 2 - 6 } & Excellent & Good & Fair & Poor & Dead & \\
\hline ICA & 23 & 2 & 0 & 1 & 0 & 26 \\
MCA & 7 & 0 & 0 & 0 & 0 & 7 \\
AComA & 19 & 3 & 0 & 0 & 1 & 23 \\
A $_{1}$ & 1 & 0 & 0 & 0 & 0 & 1 \\
DACA & 5 & 0 & 0 & 0 & 0 & 5 \\
VB & 10 & 0 & 0 & 0 & 2 & 12 \\
\hline Total & 65 & 5 & 0 & 1 & 3 & 74 \\
\hline
\end{tabular}

ICA: internal carotid artery, MCA: middle cerebral artery, AComA: anterior communicating artery, $A_{1}: A_{1}$ portion of anterior cerebral artery, DACA: distal portion of anterior cerebral artery, VB: vertebro-basilar artery

Table 5 Surgical outcome in Grade II case with ruptured cerebral aneurysms operated between 4 and 14 days after SAH

\begin{tabular}{lcccccc}
\hline \multirow{2}{*}{$\begin{array}{c}\text { Site of ruptured } \\
\text { aneurysm }\end{array}$} & \multicolumn{5}{c}{ Surgical outcome } & \\
\cline { 2 - 6 } & Excellent & Good & Fair & Poor & Dead & \\
\hline ICA & 4 & 1 & 0 & 0 & 1 & 6 \\
MCA & 4 & 0 & 0 & 0 & 1 & 5 \\
AComA & 6 & 0 & 0 & 0 & 0 & 6 \\
A $_{1}$ & 0 & 0 & 0 & 0 & 0 & 0 \\
DACA & 2 & 0 & 0 & 0 & 0 & 2 \\
VB & 2 & 2 & 0 & 0 & 0 & 4 \\
\hline Total & 18 & 3 & 0 & 0 & 2 & 23 \\
\hline
\end{tabular}

ICA: internal carotid artery, MCA: middle cerebral artery, AComA: anterior communicating artery, $\mathrm{A}_{1}$ : $\mathrm{A}_{1}$ portion of anterior cerebral artery, DACA: distal portion of anterior cerebral artery, VB: vertebro-basilar artery

Table 6 Causes of deterioration in Grade I and II cases with ruptured aneurysms (Cases operated between 4 and 14 days after $\mathrm{SAH}$ )

\begin{tabular}{cccccc}
\hline Age & (Total cases) & VS & SP & Comp. & Total \\
\hline$<65$ & $(77)$ & 2 & 1 & 1 & 4 \\
$65 \leqq$ & $(20)$ & 0 & 2 & 0 & 2 \\
\hline & $(97)$ & $2(2 \%)$ & $3(3 \%)$ & $1(1 \%)$ & $6(6 \%)$
\end{tabular}

VS: vasospasm, SP: surgical procedure, Comp.: complication

ping を試みたものの, 動脈瘤より出血を生じたため ICA の血流を遮断して動脈瘤部分を縫合したが，結果として IC occlusion を生じた例である. Comp.の 1 例は 48 歳の 症例で, 術前検査では異常がなかったが, 術後に急性心筋 梗塞をきたしたものであった。

\section{[15日以降手術群]}

全例 Grade Iであり，転帰不良例は 222 例中 8 例 (4\%)であった (Table 7)。転帰不良の原因はVS 1 例 $(0.5 \%)$ ，SP 5 例 ( $2 \%)$, Comp. 2 例（1\%)であった (Table 8 ). VSの 1 例は 45 歳の Grade I の脳底動脈瘤 で, 出血後 15 日目で手術を行った例であり, 術中静脈性 出血が対側に流入し手術側と反対側のVS を生じた例であ った，SPによる転帰不良の内訳は，ICA-AN，MCA-AN， $\mathrm{A}_{1}$-ANが 1 例ずつであり，残りの 2 例はVBA-AN であっ た. ICA-AN の 1 例は, 64 歳の large size の後交通動脈 分岐部動脈瘤で，前回の clipping が不完全でそのため再 破裂した症例であり，前回に比べ，ICA 全体が膨れ不整 形であった。前回手術で applyした clip をはずす際に rupture を生じたため, temporary clip 2 度 (17 分, 10 
Table 7 Surgical outcome in Grade I cases with ruptured cerebral aneurysms operated on 15 days or more after SAH

\begin{tabular}{lrrrrrrr}
\hline \multirow{2}{*}{$\begin{array}{c}\text { Site of ruptured } \\
\text { aneurysm }\end{array}$} & \multicolumn{5}{c}{ Surgical outcome } & \\
\cline { 2 - 6 } & Excellent & Good & Fair & Poor & Dead & \\
\hline ICA & 52 & 2 & 0 & 0 & 2 & 56 \\
MCA & 38 & 0 & 1 & 0 & 0 & 39 \\
AComA & 73 & 0 & 0 & 0 & 1 & 74 \\
A $_{1}$ & 2 & 0 & 1 & 0 & 0 & 3 \\
DACA & 4 & 0 & 0 & 0 & 0 & 4 \\
VB & 40 & 3 & 0 & 2 & 1 & 46 \\
\hline Total & 209 & 5 & 2 & 2 & 4 & 222 \\
\hline
\end{tabular}

ICA: internal carotid artery, MCA: middle cerebral artery, AComA: anterior communicating artery, $\mathrm{A}_{1}$ : $\mathrm{A}_{1}$ portion of anterior cerebral artery, DACA: distal portion of anterior cerebral artery, VB: vertebrobasilar artery

分)用いて, fenestrate clip を apply したものの, 術後麻痺 が生じ，経過観察中に死亡した例である.MCA-AN の 1 例は 55 歳で, 術中所見および術後検查で脳血管損傷や血 管閉塞は認められなかったが, 術後片麻痷をきたしたため SP 群とした. A $A_{1}$-ANの症例は術後 5 日目よりpsychiatric changeを生じ，他に原因となるような要素が存在しなか ったためSP群とした．残りの 2 例中 1 例は, 70 歳の Grade Iの高位の脳底動脈先端部動脈瘤であり, clipping により後大脳動脈拧よびその穿通枝の閉塞をきたしたもの で，1例は同側 ICA 閉塞を合併した $\mathrm{P}_{1}-\mathrm{P}_{2}$ junction AN で, 長時間の手術操作による血流障害により片麻舫を生じ た例である. Comp.の 2 例は 62 歳, 67 歳の症例でそれぞ れ急性腎不全と, 抗生物質使用に上る無顆粒球症を併発し た症例であった。

\section{考察}

破裂脳動脈瘤軽症例の手術成績は一般に良好であるとさ れており, 我々の成績も 3 日以内手術群でGrade Iは 56 例中 48 例 (86\%)，II は 110 例中 98 例 (89\%)，4-14 日手 術群で Grade I は 74 例中 70 例 (95\%), II は 23 例中 21 例 $(91 \%), 15$ 日以降手術群で 222 例中 214 例 $(96 \%)$ が転 帰良好例であった。

しかし，少数とはいえ転帰不良例が認められたため，以 下に手術時期別にその原因と対策を考察する.

\section{[3 日以内手術群]}

転帰不良 20 例を原因別に検討すると，VS が転帰不良 20 例中 10 例 (50\%) と最も多かった。長澤ら ${ }^{13)}$ はGrade I \&II の転帰不良例を $13 \%$ と報告し，そのすべてがVSによ るものであったことより, 術後のVS 対策の重要性を強調
Table 8 Causes of deterioration in Grade I cases with ruptured aneurysms (Cases operated 15 days and after)

\begin{tabular}{cccccc}
\hline Age & (Total cases) & VS & SP & Comp. & Total \\
\hline$<65$ & $(184)$ & 1 & 4 & 1 & 6 \\
$65 \leqq$ & $(38)$ & 0 & 1 & 1 & 2 \\
\hline & $(222)$ & $1(0.5 \%)$ & $5(2 \%)$ & $2(1 \%)$ & $8(4 \%)$ \\
\hline
\end{tabular}

VS: vasospasm, SP: surgical procedure, Comp.: complication

している.VS そのものの発生率は高齢者と若年者との間 に有意な差は認めないとの報告 ${ }^{3)}{ }^{177}$ がある。しかし，症候 性 VS の発現頻度は年齢により変わらないが，転帰に及ぼ す影響が異なり，高齢者においてはVSにより転帰不良と なる率が若年者に比べ有意に高率であるとする報告が多い 18) 20) 22). 著者らの結果でも， 65 歳以上の VSによる転帰 不良例が 65 歳未満に比べ有意に多かったことより，高齢 者では特にVSの対策が重要である。しかし，若年者に用 いられ有効とされている hypervolemic-hypertension therapy は呼吸循環器系への影響を考えると, 高齢者ではその 利用が困難であり, 効果も期待できないとされているため 12), 先に述べた従来の方法に加え, 血腫溶解剂 (urokinase や t-PA）を短期間用いる方法 ${ }^{6}{ }^{10)}$ を採用する必要があるか もしれないと考えている.

$\mathrm{SP}$ による転帰不良例は 20 例中 3 例 (15\%) であり， 2 例がVBA-ANであった，そのうち，1例は高位に存在す る脳底動脈分岐部動脈瘤で, neck clipping に際し穿通枝 の損傷を生じたものであった ${ }^{16)}$. 従って, 高位脳底動脈 瘤の手術に際しては, より広い視野を得る工夫が必要で, 前側頭動脈を剝離あるいは切断し, 中大脳動脈および視索 を圧排する方法や，第三脳室底経由で接近する方法 ${ }^{7}$ を考 
慮する必要があると考えられる。また，他の 1 例は解離性 椎骨動脈瘤症例であり, 動脈瘤の neck clippingに執着し たため血栓遊離を生じ，転帰不良となった例であった，従 って, 解離性動脈瘤の大部分では，その病態から考えて neck clipping が不可能であることを念頭におき，動脈瘤 全体の coating あるいは血行動態を考虑した上でのVA trapping を選択する必要がある.

Comp.による転帰不良例は 20 例中 7 例 (35\%)で，術後 生じた原因不明の内頸動脈閉塞に対しては対策を構じるこ とは困難であるが，若年者では，CT上推定される破裂動 脈瘤の検索のみでなく，急性期においても可能な限り 3 or 4 -vessel studyを行うことにより未検査の VBA-ANの 破裂を防ぎ得る可能性がある。また高齢者においては早期 離床と早期のリハビリテーションを行うことにより廃用性 の筋力低下を防止することができると考えられた。

\section{[4-14 日手術群]}

原因別に検討すると，VSによるものは転帰不良 6 例中 2 例 $(33 \%)$ で，これらはともに出血後 10 日前後に手術が なされた症例であった。これら以外にVSによる転帰不良 例が存在しないのは，この群ではVSの出現時期を過ぎて から手術が施行された症例が多かったためと考えられる.

4-14 日手術群での転帰不良例の最大の原因はSPであり， 転帰不良 6 例中 3 例 $(50 \%)$ を占め, 手術成績改善には個々 の症例において手術法を工夫する必要があると思われる. まずVBA-ANの 1 例は高位に存在した脳底動脈瘤であり 3 日以内手術群のところで述べた注意が必要である. 動脈 硬化の強い neck 近くに clipping を行ったために後交通動 脈閉塞をきたした ICA-ANの 1 例では，親動脈より $3 〜 4$ $\mathrm{mm}$ 離れた部位で clipping を行う工夫が必要と考えられた。 更に本シリーズでの ICA 上壁にできた AN は, 高橋ら ${ }^{21)}$ がチマメ状動脈瘤として報告しているタイプの動脈瘤で壁

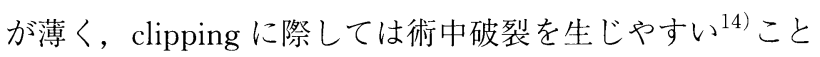
が予想できた。従って本例では, clipping を強行すること なく, Oxycel gauze with biobond で親血管を含め動脈瘤 全体を coating する方法が最も良かったのではないかと考 えている.

Comp.による転㷌不良例は 1 例 $(17 \%)$ であった。急性 心筋梗塞例は術前の心電図では異常所見は認められなかっ たものであり原因は不明である。

\section{[15 日以降手術群]}

原因別に検討すると，転帰不良 9 例中 SP が 5 例 (56\%) と最も多く, Comp. 2 例 (22\%), VS 1 例 (11\%)であった. SP のうち， 2 例が VBA-AN で， 1 例が高位の脳底動 脈先端部動脈瘤の症例であったが, やはり 3 日以内手術群
のところで述べた注意が必要である，他の 1 例は同側内頸 動脈閉塞を合併した特殊な例で, 拡張蛇行した後交通動脈 が手術操作の邪魔になったことから， subtemporal approach を採用すべきであったと思われる．ICA-ANの 再手術の症例では, 前回手術の際に行った coating を除去 する操作と, apply されていた clip を除去する操作が必要 であった，著者らは，残存 neckに対する完全な coating は非常に有効な手段と考えているが，同部位の再手術に際 してはその操作を困難なものとする原因になり得ることは 否定できず，結果として本症例ではそれを除去し，AN と 親血管との正確な位置関係を把握するのが困難であった。 また， clip を除去する際にもあらかじめ temporary clip に て破裂による出血を予防する必要があったのではないかと 考えている. Comp.による転帰不良の 2 例はいずれも術 前検査では異常を認めず，術後経過良好であり，合併症を 生じた時点で対症療法を行ったが急速に悪化した例であり 術後管理の難しさを示している例であった。

\section{結 論}

破裂脳動脈瘤軽症例における術後悪化例について retrospective に検討した。

その結果, Grade I, IIでの手術成績を向上させるため には，3 日以内手術群では，65歳以上の例での VSへの 対策が特に重要であり，4 日以降手術群では手術操作によ る悪化例をなくすことが重要で, 特殊な条件をもつ症例で は，その条件に合った手術法の工夫を行うべきであると考 えられた。

\section{文献}

1) 後藤 修, 田村 晃, 安井信之, ほか：Glasgow Coma Scaleによる破裂動脈瘤の術前評価一急性期手術例における 6 力月転帰との対応一. 脳神経外科 21: 37-43, 1993

2）後藤修, 田村 晃, 仁瓶博史, ほ力: 破裂腮動脈瘤早期 手術後の血管攣縮と 6 力月転帰—Glasgow Coma Scale によ 万術前重症度との関連一. 脳神経外科 21: 221-226, 1993

3）平田好文, 松角康彦, 児玉万典, ほか：高齢者破裂脳動脈 瘤の問題点 (特に術後合併症, 術後管理面から). Neurol Med Chir (Tokyo) 27: 1066-1072, 1987

4) Hunt WE, Kosnik EJ : Timing and preoperative care in intracranial aneurysm surgery. Clin Neurosurg 21: 79-89, 1973

5) Jae Hong Sim: The clinical analysis of surgical timing for ruptured intracranial aneurysms. In: Kikuchi H, Fukushima T, Watanabe K (eds), Intracranial Aneurysms. Surgical Timing and Techniques, Nishimura, Niigata, 1986, pp 143156

6) Kodama N, Sasaki T, Kawakami M, et al: Prevention of vasospasm : Cisternal irrigation therapy with urokinase and ascorbic acid. In: Sano K, Takakura K, Kassell NF, Sasaki $\mathrm{T}(\mathrm{eds})$, Cerebral Vasospasm, University of Tokyo Press, Tokyo, 1991, pp 314-316

7) Kodama N, Sasaki T, Sakurai Y: Transthird ventricular 
approach for a high basilar bifurcation aneurysm - Report of three cases-. J Neurosurg 82: 664-668, 1995

8) Ludwig M. Auer : Management of patients with subarachnoid hemorrhage from ruptured cerebral aneurysms: What remains to be done ?. In: Kikuchi $\mathrm{H}$, Fukushima T, Watanabe K(eds), Intracranial Aneurysms. Surgical Timing and Techniques, Nishimura, Niigata, 1986, pp 134-142

9) Miyaoka M, Sato K, Ishii S : A clinical study of the relationship of timing to outcome of surgery for ruptured cerebral aneurysms -A retrospective analysis of 1662 cases-. J Neurosurg 79: 373-378, 1993

10) Mizoi K, Yoshimoto $T$, Fujiwara S, et al: Prevention of vasospasm by clot removal and intrathecal bolus injectiom of tissue-type plasminogen activator : Preliminary report. Neurosurgery 28: 807-813, 1991

11）森 貴久, 有澤雅彦, 本田信也, ほか：クモ膜下出血患者 の長期予後. 脳神経外科 21: 431-435, 1993

12）長澤史朗, 大槻宏和, 米川泰弘, ほか：高齢者破裂脳動脈 瘤 60 例の検討．脳神経外科 16: 17-21, 1988

13）長澤史朗, 半田 肇：破裂脳動脈瘤の手術の適応と夕イミ ング. Clin Neurosci 3: 873-875, 1985

14）長嶺義秀，小笠原邦昭，溝井和夫，ほか：Wrapping \& clipping の追加 clip により術中破裂をきたした内頸動脈チマメ 状動脈瘤の 1 例. 第13回 The Mt. Fuji Workshop on CVD
講演集，1995, pp 89-92

15）貫井英明，佐々木秀夫，金子的実，ほか：破裂脳動脈瘤重 症例の手術成績とそれに基づく手術適応．脳卒中の外科 $\mathbf{1 7}$ : 258-264, 1989

16）貫井英明：破裂脳底動脈瘤の手術。北海道脳神経疾患研究 所医誌 3: 11-23, 1990

17）小川 彰, 中里信和：総説, 早期手術, 高齢者関連論文, 脳血管攣縮 4, 中外医学社, 東京, 1989, pp 2-15

18) Ohmoto $\mathrm{T}$, Mino $\mathrm{S}$, Nishimoto $\mathrm{A}$, et al: Operative results of ruptured intracranial aneurysms in aged patients. Neurol Med Chir (Tokyo) 20: 721-728, 1980

19) Sano H, Jain VK, Katou $Y$, et al: Timing of surgery for ruptuerd aneurysms, In: Kikuchi H, Fukushima T, Watanabe K (eds), Intracranial Aneurysms. Surgical Timing and Techniques, Nishimura, Niigata, 1986, pp 168-176

20）鈴木明文, 安井信之, 波出石弘, ほか: 高齢者破裂脳動脈 瘤症例に抢ける脳血管攣縮. Neurol Med Chir (Tokyo) 28: 786-790, 1988

21）高橋 明, 鈴木二郎, 藤原 悟, ほか : 内頸動脈 $\mathrm{C}_{2}$ 部チマ メ状動脈藘の手術. 脳卒中の外科 16: 72-77, 1988

22）矢野 隆，鮄川哲二，上家和子，ほか：高齢者破裂脳動脈 瘤患者の検討. 脳卒中 8: 231-236, 1986

23) Yaşargil MG : Microneurosurgery II, George Thieme Verlag, Stuttgart / New York, 1984, pp 7-16 